\title{
Notice of a meteoric stone seen to fall at Bath, south dakota
}

\section{A. E. Foote}

To cite this article: A. E. Foote (1893) Notice of a meteoric stone seen to fall at Bath, south dakota, Philosophical Magazine Series 5, 35:213, 152-152, DOI: 10.1080/14786449308620348

To link to this article: http://dx.doi.org/10.1080/14786449308620348

曲 Published online: 08 May 2009.

Submit your article to this journal ¿

Џll Article views: 2

Q View related articles $\sqsubset$ 


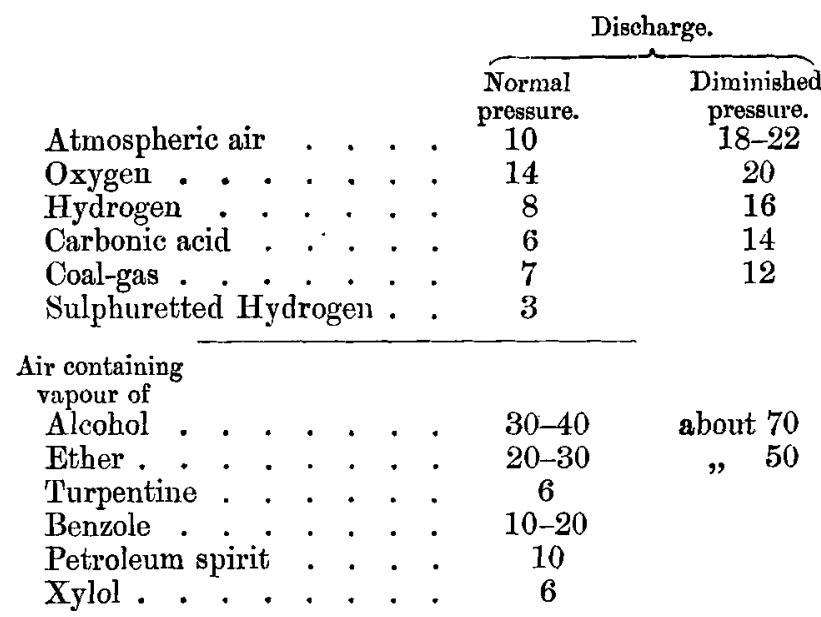

In this the mean strength of the discharge in dry atmospheric air is taken at 10-Inauyural Dissertation, Bonn, 1881 ; Beiblätter der Physik, vol. xvii. p. 60 .

\section{NOTICE OF A METEORIO STONE SEEN TO FALL AT BATH, SOUTH DAKOTA. BY A. E. FOOTE.}

On the 29th day of August, 1892, about 4 o'clock in the afternoon, while Mr. Lawrence Freeman and his son were stacking upon his farm two miles south of Bath, they were alarmed by a series of heavy explosions. On looking up they saw a meteoric stone flying through the air followed by a cloud of smoke. Its course was easily traced to the point where it fell within about twenty rods from where they were standing. The stone penetrated the hardened prairie to a depth of about sixteen inches, and when reached it was found to be so warm that gloves had to be used in bandling it. Three small pieces of an ounce or two each had apparently been blown off by the explosions, but the stone still weighed $46 \frac{3}{4} \mathrm{lb}$. One of these small pieces was found by some men not far distant, and was broken up and distributed among them. The explosions were plainly heard by a large number of people at Bath, two miles away, and at Aberdeen, nine miles away, it sounded like distant cannonading. The exterior of the stone presents the usual smooth black crust. The interior is quite closegrained, resembling in texture the stones from Möcs. The iron is abundantly disseminated through the mass; and although the grains are small, they are easily distinguished and separated on pulverizing.

Preliminary tests made by Mr. Amos P. Brown, of the Mineralogical Department of the University of Pennsylvania, prove the presence of nickel and cobalt in considerable quantity.-Silliman's Journal, January 1893. 